\title{
Ammonia excretion rate of Clytia spp. hydro- medusae (Cnidaria, Thecata): effects of individual dry weight, temperature and food availability
}

\author{
Sophie Matsakis*
}

Station Zoologique, BP 28, F-06230 Villefranche-sur-Mer, France

\begin{abstract}
In order to estimate the in situ growth budget of Clytia spp. hydromedusae, ammonia excretion rates were measured for a variety of individual weights at 4 temperatures $(15,18,21$ and $25^{\circ} \mathrm{C}$ ), using 4 food concentrations $\left(7,15,25\right.$ and 50 copepods $1^{-1}$ ). Excretion rate increased with medusa dry wt and was directly correlated with temperature and food availability. Excretion values ranged between 0.04 and $0.936 \mu \mathrm{g}$-at. $\mathrm{N}-\mathrm{NH}_{4} \mathrm{~d}^{-1}$ ind. ${ }^{-1}$ Weight-specific excretion was independent of medusa dry weight $(W)$ and ranged between 1.9 and $18.1 \mu \mathrm{g}$-at. $\mathrm{N}-\mathrm{NH}_{4} \mathrm{mg}^{-1} \mathrm{~d}^{-1}$, according to experimental conditions. The daily nitrogen turnover (only considering ammonia) ranged from $6 \%$ at the lowest temperature and food concentration to $33 \%$ at $21^{\circ} \mathrm{C}$ and the highest food concentration. The calculation of the growth budget, which represents the difference between quantity of nitrogen in food ingested and nitrogen lost through ammonia excretion extrapolated to the natural environment, showed high values during the spring, up to $55 \mu \mathrm{g} \mathrm{N} \mathrm{d}^{-1}$ ind. $^{-1}$, and slightly negative values during the rest of the year.
\end{abstract}

\section{INTRODUCTION}

Zooplankton excretion plays an important role in the nitrogen cycle of marine ecosystems; it represents a loss in nitrogen or phophorus from zooplanktonic populations, but also a feedback of nutrients to primary producers and bacteria (Harris 1959. Jawed 1973. Båmstedt 1985). Regenerated nitrogen including that excreted by zooplankton can be very important for phytoplankton growth (Martin 1968, Eppley et al. 1973, Dagg et al. 1980). Ammonia constitutes most of the nitrogen released by zooplankton (Corner \& Davies 1971, Mayzaud \& Dallot 1973, Kremer 1975, 1977 ) and is prefer to other forms of nitrogen by phytoplankton (Strickland et al. 1969, MacIsaac \& Dugdale 1972, Båmstedt 1985). The excretion by different zooplankton groups has been well studied. Copepods as well as ctenophores and total zooplankton have received considerable attention (Corner \& Davies

\footnotetext{
- Present address: University of Bergen, Department of Fisheries and Marine Biology, High Technology Center N-5020 Bergen, Norway
}

1971, Ikeda 1974, 1985, Nival et al. 1974, Kremer 1975 1977, 1982, Kremer et al. 1986, Youngbluth et al. 1988) The excretion rate of an organism increases allometrically with individual length (Nival et al. 1974, Ikeda 1985) while the excretion rate per weight unit decreases with (Corner et al. 1965) or is independent of individual length (Kremer 1977, Morand et al. 1987).

Despite the recent increase in publications on gelatinous zooplankton metabolism, knowledge of hydromedusa ammonia excretion is still limited. Biggs (1977) showed the importance of total gelatinous predators as a nitrogen source in the North Atlantic Ocean, where their excretion is sufficient to supply 39 to $63 \%$ of the phytoplankton nitrogen requirements. Similarly, the large number of trachymedusae Aglantha digitale in a productive zone of the Northeast Atlantic Ocean was presumed by Williams \& Conway (1981) to be an important source of nitrogen for the phytoplankton production.

The goal of the present study was to provide data on ammonia excretion of hydromedusae of the genus Clytia in order to better understand their ecology by calculating their growth budget as a function of envi- 
ronmental variables. Food availability and temperature are 2 of these important environmental factors. By suitable preconditioning in controlled food regimes and temperatures which might occur in nature, we estimated the rate of ammonia excretion by Clytia spp. and determined the effect of body mass, temperature and food availability on excretion. Constant food availability and temperature are not realistic, however, in describing what animals may be exposed to in the field, where there is undoubtedly a patchy distribution of prey (Hamner et al. 1975, Harbison et al. 1978, Alldredge et al. 1984). But, according to Kremer (1982), if we are to understand how animals function in situ we need to go beyond investigation of metabolic rates and products under stable conditions, and to describe the dynamics of the changes in metabolic rates in response to various temperatures and food availabilities.

\section{MATERIAL AND METHODS}

Excretion experiments. Among the gelatinous predators in the Bay of Villefranche-sur-Mer (France), hydromedusae form an important group which can be seasonally abundant (Goy 1968, Matsakis 1990). Clytia spp. is an important component of the macroplankton in the Bay. The taxonomy of this genus is confused (Kramp 1961, Cornelius 1982). Goy (1968) described 7 Clytia spp. hydrozoa in the Bay of Villefranche-surMer, but only 3 are known to release medusae: Clytia gravieri, C. noliformis and C. johnstoni (Phialidium haemisphericum). Because of the difficulty of determining hydromedusan species, we refer to Clytia spp. to indicate the animals used in this study.

Clytia spp. were collected with a Regent type net (1 m diameter, mesh size 680 to $690 \mu \mathrm{m}$ ) at Point ' $\mathrm{B}$ ' in the Bay (Fig 1) towed horizontally for 15 min at a depth of $30 \mathrm{~m}$. Within 1 h the medusae were transferred to 51 rearing beakers, placed in thermostatted baths.

The medusae were then preconditioned for $1 \mathrm{wk}$ to the experimental conditions of temperatures and food concentrations: food and rearing water were renewed every $2 d$, food was added every $12 \mathrm{~h}$. During that period, we used an arbitrary density of 1 medusa $\mathrm{l}^{-1}$. Medusae were fed with the most abundant copepod species in the size class of 250 to $550 \mu \mathrm{m}$. Copepods were collected with a $200 \mu \mathrm{m}$ mesh net (WP II type), screened and transfered to 51 rearing beakers before being given to the medusae.

Excretion measurements were done between July and November 1989 at 15, 18, 21 and $25^{\circ} \mathrm{C}$; these values cover the annual range of temperatures in the Bay. Medusae 2 to $11 \mathrm{~mm}$ in diameter (corresponding to between 5 and $145 \mu \mathrm{g}$ individual dry wt), were grouped in 16 rearing beakers, each corresponding to

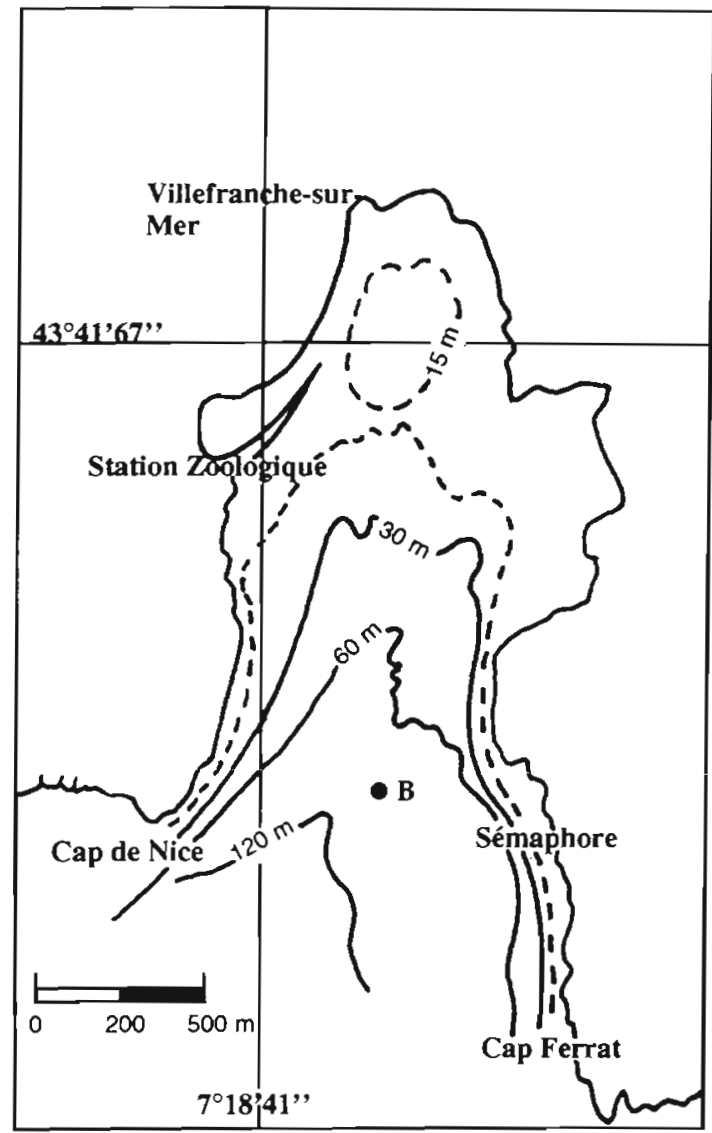

Fíg. 1 The Bay of Villefranche-sur-Mer showing location of Point B

a combination of 1 of the 4 temperatures and 1 of 4 food concentrations, $7,15,25$ and 50 copepods $1^{-1}$, used for growth experiments (see Matsakis 1990). After this rearing period, medusae were washed in filtered seawater $(0.2 \mu \mathrm{m}$ mesh), sorted by size and distributed in experimental flasks ( $250 \mathrm{ml}$ capacity) of filtered seawater by size; the number of individuals per flask varied from 1 to 5 for medusae $\geq 5 \mathrm{~mm}$ diameter and up to 12 for smaller medusae. Ammonia concentration was determined after $4 \mathrm{~h}$ incubation: a longer period led to damage of the smaller individuals. Prior to the experiments all incubation flasks were acid-washed and thoroughly rinsed with distilled water. Three control flasks (containing only filtered seawater) were used to take into account any contamination by ammonia before each measurement series. Ammonia analyses were carried out with a Technicon II autoanalyzer using the method of Koroleff (1969), following Tréguer \& Le Corre (1975) sampling the flasks directly; three $2.5 \mathrm{ml}$ samples were analysed per flask. A calibration curve was used for each experiment. The precision of measuring $0.1 \mu \mathrm{g}$-at. $\mathrm{N}-\mathrm{NH}_{4} \mathrm{l}^{-1}$ was $\pm 4 \%$. 
Clytia spp. dry weights were not measured during the experiments, but were estimated from the relationship between dry wt and medusae diameter determined for Clytia spp. (= Phialidium spp.) by Matsakis \& Nival (1989): $W=15.65 D-26.8(\mathrm{n}=36, \mathrm{r}=0.80, \mathrm{p} \leq 0.05)$, where $W=$ dry weight $\left(\mu \mathrm{g}\right.$ ind $\left.{ }^{-1}\right)$; and $D=$ diameter $(\mathrm{mm})$.

Calculations. The relationships between excretion rate $\left(E ; \mu g\right.$-at. $\mathrm{N}-\mathrm{NH}_{4}$ ind $\left.{ }^{-1} \mathrm{~h}^{-1}\right)$, individual dry weight $\left(W_{i} \mu \mathrm{g}\right.$ ind. $\left.{ }^{-1}\right)$, and temperature $T\left({ }^{\circ} \mathrm{C}\right)$ are usually as follows (Nival et al. 1974): for a given food regime and at constant temperature:

$$
E(W)=a W^{b},
$$

and for a given food regime and at constant weight:

$$
E(T)=c d^{T},
$$

where $a, b, c$ and $d$ are constants. These values can be determined by simple regression analysis:

$$
\begin{aligned}
& \log E=\log a+b \log W \\
& \log E=\log c+T \log d
\end{aligned}
$$

where $\log$ is the base-10 logarithm.

If we consider dry weight $(W)$ and temperature $(T)$ as 2 independent variables, we can describe simultaneously their effect on the excretion rate:

$$
\begin{gathered}
a=c d^{T} \\
E(W, T)=c W^{b} d^{T}
\end{gathered}
$$

A multiple regression analysis can be used to determine the value of the constants $b, c$ and $d$ :

$$
\log E=\log c+b \log W+T \log d
$$

This calculation assumes that the constant $b$ is independent of temperature and $d$ is independent of individual dry weight.

Excretion rate is also affected by food concentration $F$ (copepods $1^{-1}$ ). We assume that only the value of the constant $c$ (Eq. 3) is affected by $F$. Thus, excretion rate of Clytia spp. can be expressed by the following equation:

$$
E=p r^{F} d^{r} W^{b}
$$

The values of the constants $p, r, d$ and $b$ can be determined by a multiple regression analysis:

$$
\log E=\log p+F \log r+T \log d+b \log W
$$

where $E=$ ammonia excretion rate $\left(\mu \mathrm{g}\right.$-at. $\mathrm{N}-\mathrm{NH}_{4} \mathrm{~h}^{-1}$ ind $\left.^{-1}\right) ; W=$ dry weight $\left(\mu \mathrm{g}\right.$ ind.$\left.^{-1}\right) ; F=$ food concentration (copepods $l^{-1}$ ); $T=$ temperature $\left({ }^{\circ} \mathrm{C}\right)$; and $p, r, d$ and $p$ are constants.
As an index to describe the temperature effect on biological rate, $Q_{10}$ is commonly used (Ikeda 1985). It can be estimated from the value of the coefficient ' $d$ ' (in Eqs, 1, 2 \& 5):

$$
Q_{10}=d^{10}
$$

\section{RESULTS}

All significant relationships found between excretion rate and individual dry weight (Eq. 1) for each temperature and each food concentration are given in Table 1. Excretion rates of Clytia spp. increased significantly with weight, except at 15 and $21^{\circ} \mathrm{C}$ with a food concentration of 15 copepods $\mathrm{l}^{-1}$, for which the slopes of the regressions (b) were not significantly different from zero.

Comparison by a Reeve's test (Reeve 1940) for equality of slopes, with $F_{\max }(p=0.05)$ for each temperature, of all the regression lines showed that at 15 , 18 and $21^{\circ} \mathrm{C}$ the values of the slopes $b$ are not significantly different, but that their origins $(\log$ a) are significantly different. We can therefore assume that at

\begin{tabular}{|c|c|c|c|c|c|c|}
\hline Temp. & $\begin{array}{l}\text { Food } \\
\text { conc. }\end{array}$ & $b$ & a & $\mathrm{n}$ & $\mathrm{r}$ & $\mathrm{p}$ \\
\hline \multirow[t]{4}{*}{$15^{\circ} \mathrm{C}$} & 7 & 0.997 & -4.207 & 8 & 0.828 & $\cdot$ \\
\hline & 15 & - & - & -- & - & $n s$ \\
\hline & 25 & 1.105 & -3.612 & 11 & 0.917 & $\cdots$ \\
\hline & 50 & 1.03 & -4.011 & 10 & 0.379 & $\cdots$ \\
\hline \multirow[t]{4}{*}{$18^{\circ} \mathrm{C}$} & 7 & 0.901 & -3.819 & 11 & 0.89 & $\because$ \\
\hline & 15 & 0.884 & -3.785 & 9 & 0.931 & $\cdots$ \\
\hline & 25 & 1.412 & -4.443 & 11 & 0.923 & $\cdots$ \\
\hline & 50 & 0.608 & -3.150 & 10 & 0.77 & - \\
\hline \multirow[t]{4}{*}{$21^{\circ} \mathrm{C}$} & 7 & 1.002 & -4.065 & 11 & 0.899 & $\because$ \\
\hline & 15 & - & - & - & - & ns \\
\hline & 25 & 1.369 & -3.881 & 13 & 0.981 & $\cdot \cdot$ \\
\hline & 50 & 1.319 & -3.892 & 12 & 0.943 & $\cdots$ \\
\hline \multirow[t]{4}{*}{$25^{\circ} \mathrm{C}$} & 7 & 0.571 & -3.228 & 9 & 0.669 & $\cdots$ \\
\hline & 15 & 0.924 & -3.753 & 8 & 0.971 & * \\
\hline & 25 & $0.468^{\mathrm{d}}$ & -3.296 & 10 & 0.828 & * \\
\hline & 50 & 1.555 & -4.883 & 11 & 0.957 & 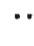 \\
\hline
\end{tabular}
15,18 and $21^{\circ} \mathrm{C}$ the allometric coefficient $b$ is independent of food availability. At $25^{\circ} \mathrm{C}$, the slopes of the 4 regressions (Table 1 ) were significantly different as were their origins.

Table 1. Clytia spp. Regressions of excretion rate ( $E, \mu g$-at. $\mathrm{N}-\mathrm{NH}_{4} \mathrm{~h}^{-1}$ ind $\left.^{-1}\right)$ vs individual dry wt $(W, \mu \mathrm{g})$ using $\log E=$ $b \log W+a(E q .1)$ at the experimental temperatures and food concentrations (copepods $\mathrm{l}^{-1}$ ). ns: not significant; $\cdot p<0.05$; $\because p<0.001$ 
Considering all regression lines, we performed a conformity test (Sokal \& Rohlf 1981), for which we proposed the null hypothesis that the slope $b=1$, and observed that the slopes were not significantly different from 1, except for the equation obtained at $25^{\circ} \mathrm{C}$ and 25 copepods $I^{-1}$ (Table 1 ).

From these results we could estimate the influence of dry wt and temperature on excretion at each food concentration (Eqs. $1 \& 2$ ) by calculating 4 multiple regressions (Table 2). A t-test showed that the regression coefficients for weight $(b)$ and those for temperature (d) were significantly different from zero $(p<0.05)$ at food concentrations of 7,15 and 25 copepods $l^{-1}$, but not at 50 copepods $1^{-1}$.
When the allometric coefficient $b$ (Eq. 1) is 1, the specific excretion rate Es $\left(\mu \mathrm{g}\right.$-at. $\left.\mathrm{N}-\mathrm{NH}_{4} \mathrm{~h}^{-1} \mu \mathrm{g}^{-1}\right) \mathrm{can}$ be calculated by dividing the excretion rate by the dry wt; Es is then independent of dry wt:

$$
\begin{gathered}
E S=c d^{r} \\
\log E S=\log c+T \log d
\end{gathered}
$$

A simple regression line was thus determined for each food concentration (Fig. 2). Considering linear regressions over the whole range of temperatures (15 to $25^{\circ} \mathrm{C}$ ), only those for the food concentrations of 7 and 15 copepods $l^{-1}$ were significant $(p=0.05)$. For other food concentrations, the relation was significant $(\mathrm{p}=0.05)$ only for temperatures between 15 and $21^{\circ} \mathrm{C}$.

Table 2. Clytia spp. Multiple regressions of excretion rate $\left(E, \mu \mathrm{g}-\mathrm{at} . \mathrm{N}-\mathrm{NH}_{4} \mathrm{~h}^{-1}\right.$ ind $\left.{ }^{-2}\right)$ vs individual dry wt ( $\left.W, \mu \mathrm{g}\right)$ and temperature $\left(T,{ }^{\circ} \mathrm{C}\right)$ using $\log E=\log c+b \log W+T \log d(E q .3)$ at the experimental food concentrations (copepods $\left.l^{-1}\right)$. $t_{(d)}, t_{(b)}$ values of the $t$-test for the coefficients $d$ and $b$

\begin{tabular}{|cccccccccc|}
\hline Food concentration & $T$ & $\log c$ & $b$ & $\log d$ & $\mathrm{n}$ & $\mathrm{r}$ & $\mathrm{p}$ & $t_{(d)}$ & $t_{(b)}$ \\
\hline 7 & $15-25$ & -4.186 & 0.863 & 0.019 & 38 & 0.835 & 0.001 & 2.726 & 8.52 \\
15 & $15-25$ & -3.905 & 0.669 & 0.025 & 38 & 0.78 & 0.05 & 3.597 & 6.443 \\
25 & $15-21$ & -4.444 & 1.239 & 0.031 & 38 & 0.736 & 0.001 & 1.987 & 9.372 \\
50 & $15-25$ & -4.34 & 1.199 & 0.012 & 43 & 0.729 & 0.001 & 0.938 & 6.783 \\
\hline
\end{tabular}
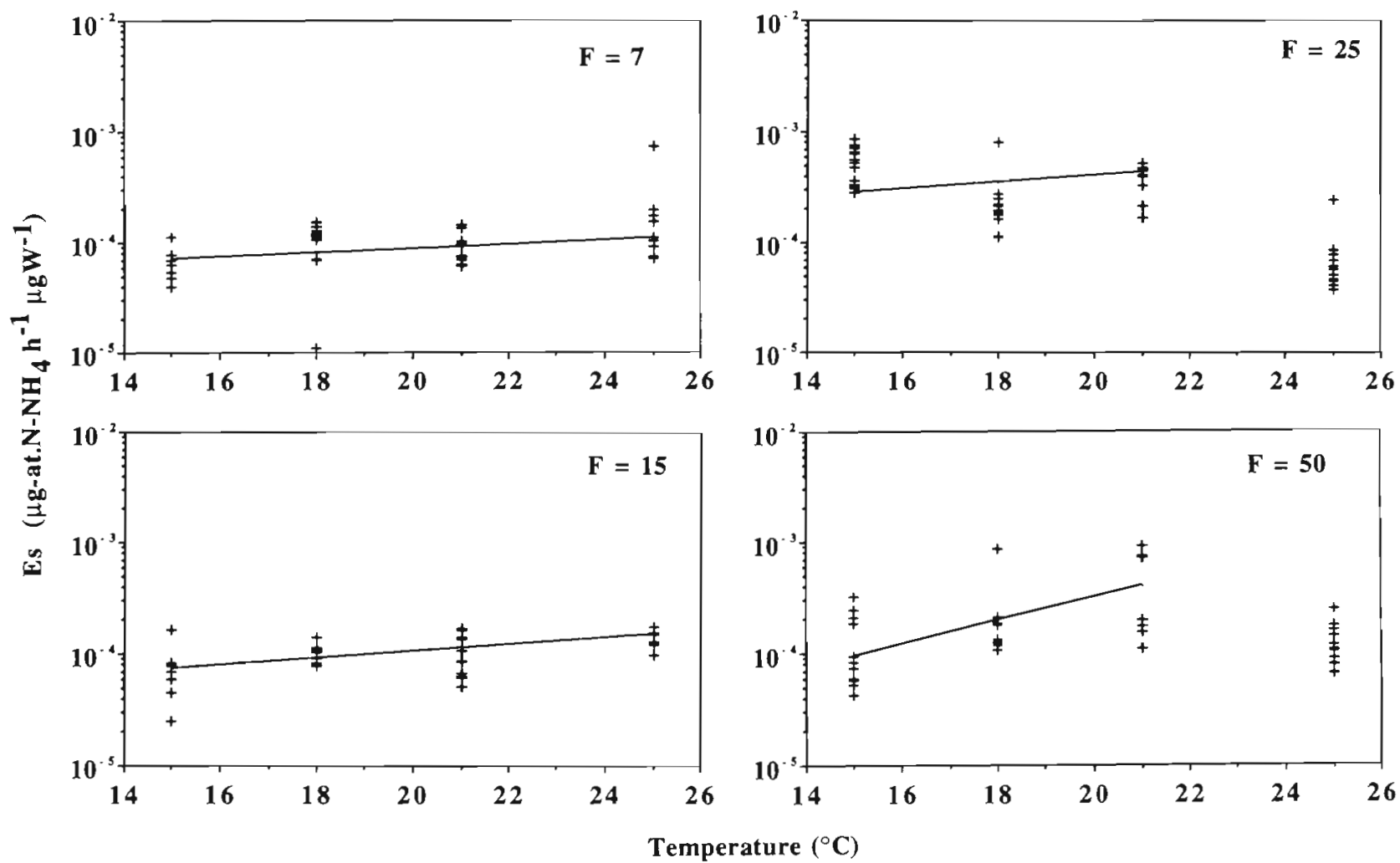

Fig. 2. Clytic spp. Specific excretion rate as a function of temperature $\left({ }^{\circ} \mathrm{C}\right)$ for each food concentration $\left(F_{\text {, copepods }}{ }^{-1}\right)$ used during the experiments 
The $Q_{10}$ varied with food concentrations (Table 3) from 1.54 at $F=7$ copepods $l^{-1}$ to 2.04 at $F=25$ copepods $1^{-1}$; at $F=50$ copepods $1^{-1}$ the $Q_{10}$ value was only 1.32. A linearity test on the Eq. (2) showed that the hypothesis of a constant $Q_{10}$ over the entire temperature range $\left(15\right.$ to $25^{\circ} \mathrm{C}$ ) could not be accepted at a food concentration of 25 copepods $1^{-1}$; it could only be accepted when temperatures ranged between 15 and $21^{\circ} \mathrm{C}$.

Table 3. Clytia spp. $Q_{10}$ values and confidence intervals $(\mathrm{CI}, \mathrm{p}=$ 0.05 ) for individuals reared at the experimental food concentrations (copepods $!^{-1}$ ) and different temperature ranges $\left({ }^{\circ} \mathrm{C}\right.$ )

\begin{tabular}{|cccc|}
\hline Food concentration & Temperature & $Q_{10}$ & CI \\
\hline 7 & $15-25$ & 1.54 & $(1.12,2.13)$ \\
15 & $15-25$ & 1.78 & $(1.28,2.39)$ \\
25 & $15-21$ & 2.04 & $(0.98,4.37)$ \\
50 & $15-25$ & 1.32 & $(0.72,2.39)$ \\
\hline
\end{tabular}

The results also revealed differences between excretion measurements at each food concentration. A temperature of $25^{\circ} \mathrm{C}$ is critical for Clytia spp.; medusae did not feed, decreased in size and died quite rapidly (see Matsakis 1990). The increase in Clytia spp. weight specific excretion rate was significant only at 15,18 and $21^{\circ} \mathrm{C}$ and Eq. (5) was thus fitted only for this temperature range: $\log P=-4.829$, $\log r=0.009, \log d=0.047$ and $b=0.962(r=0.75$, $\mathrm{p}=0.05$ ). In this case, regression coefficients for $T, F$ and $W$ were significantly different from zero, $p<0.05$ $\left(t_{(d)}=4.374, t_{(s)}=5.711, t_{(b)}=9.644\right)$.

From Eq. (5) we could determine the specific excretion rate Es ( $\mu$ g-at. $\mathrm{N}-\mathrm{NH}_{4} \mathrm{~h}^{-1} \mu \mathrm{g}^{-1}$ ) of Clytia spp. as a function of temperature $T\left({ }^{\circ} \mathrm{C}\right)$ and food concentration $F$ (copepods $1^{-1}$ ) (Table 4):

$$
E S=p r^{F} d^{T}
$$

where $p, r$ and $d$ are constants.

Using the relationship between nitrogen weight of Clytia spp. and diameter determined by Matsakis \& Nival (1989), we could estimate the nitrogen specific excretion rate and corresponding daily nitrogen turnover (Table 5). The daily turnover increased with food concentration and temperature and ranged between 6.14 and $33.60 \%$ (Table 5).

\section{DISCUSSION}

Numerous studies deal with excretion rate of zooplankton, but data on excretion of hydromedusae are still limited. Thus comparisons of the present data with
Table 4. Clytia spp. Specific excretion rates (Es, $\mu$ g-at. $\mathrm{N}-\mathrm{NH}_{4} \mathrm{~d}^{-1} \mathrm{mg}^{-1}$ ) at the experimental food concentrations (copepods $\mathrm{L}^{-1}$ ) and temperatures

\begin{tabular}{|ccc|}
\hline Temperature & Food concentration & $E_{S}$ \\
\hline $15^{\circ} \mathrm{C}$ & 7 & 1.90 \\
& 15 & $-^{a}$ \\
& 25 & 2.78 \\
& 50 & 4.58 \\
$18^{\circ} \mathrm{C}$ & 7 & 2.64 \\
& 15 & 3.11 \\
& 25 & 3.80 \\
& 50 & 6.24 \\
$21^{\circ} \mathrm{C}$ & 7 & 3.43 \\
& 15 & $-{ }^{a}$ \\
& 25 & 8.94 \\
& 50 & \\
${ }^{a} b=0$; see Table 1 & & \\
\hline
\end{tabular}

Table 5. Clytia spp. Daily nitrogen turnover (\% $\left.\mathrm{N}-\mathrm{NH}_{4} \mathrm{~d}^{-1}\right)$ at the experimental temperatures and food concentrations (only ammonia is considered)

\begin{tabular}{|ccccc|}
\hline $\begin{array}{c}\text { Temperature } \\
\left({ }^{\circ} \mathrm{C}\right)\end{array}$ & \multicolumn{4}{c|}{$\begin{array}{c}\text { Food concentrations } \\
\left.\text { (copepods }{ }^{-1}\right)\end{array}$} \\
\hline 15 & 7 & 15 & 25 & 50 \\
18 & 6.14 & 7.40 & 9.28 & 16.38 \\
21 & 8.79 & 10.55 & 13.23 & 23.35 \\
& 12.66 & 15.16 & 19.05 & 33.60 \\
\hline
\end{tabular}

those of other studies are very restrained and only try to establish whether hydromedusan metabolic rates are very different from those of other gelatinous carnivores. Excretion rates for Clytia spp. reared in different experimental conditions ranged between 0.040 and $0.936 \mu \mathrm{g}$-at. $\mathrm{N}-\mathrm{NH}_{4} \mathrm{~d}^{-1}$ ind. ${ }^{-1}$. These values are in the same range of those measured by Morand et al. (1987) for ephyrae of scyphomedua Pelagia noctiluca which ranged between 0.099 and $1.180 \mu \mathrm{g}$-at. $\mathrm{N}-\mathrm{NH}_{4} \mathrm{~d}^{-1}$ ind. $^{-1}$. Larger gelatinous predators such as the ctenophores Mnemiopsis leidyi and Mnemiopsis mccradyi have lower ammonia excretion rates, 0.01 to $0.04 \mu \mathrm{g}$-at. $\mathrm{N}-\mathrm{NH}_{4} \mathrm{~d}^{-1}$ ind $^{-1}$ (Kremer 1977, 1982).

The values of the exponent $b$ determined in our experiments $(0.5$ to 1.5$)$ are in the same range of the values reported for other gelatinous zooplanktonic species (Biggs 1977, Morand et al. 1987, Youngbluth et al. 1988, Schneider 1989) but higher than those of total zooplankton ( 0.76 to 0.83 ; Ikeda 1985$)$. These variations are dependent in part on the range of weights explored and on the behaviour and ecology of each group. Thus active species, such as the scyphomedusan Pelagia noctiluca and lobate ctenophores, which are active 
swimmers, have respiration and excretion rates 1 to 3 times higher than those of passive species (Biggs 1977). Ammonia excretion rate of Clytia spp. is more important when medusae are reared at $21^{\circ} \mathrm{C}$; at this temperature they are also more active (Matsakis 1990). It is therefore expedient to look at some possible sources of error that might have caused us to over- or underestimate these excretion data. Clytiaspp. medusae possess traits which both unite them with, and distinguish them from, other gelatinous predators, so they can show the same behavior patterns as ctenophores and change their excretion rates by pulsatile excretion (Kremer \& Kremer 1988). Also, when medusae are fed in small rearing tanks, consumption rates may lead to rapid changes in prey densities. We tried to reduce these changes by using low predator densities ( 1 medusa $l^{-1}$ ), which also reduced interactions between predators, and by adding new prey twice a day.

In most of our measurements, the values of $b$ were not significantly different from 1, indicating the absence of significant difference between weight specific excretion rate of young Clytia spp. and of adults. Allometric coefficients equal to 1 were also found for the ctenophores Pleurobrachia bachei, Mnemiopsis mccradyi and Mnemiopsis Jeidyi (Hirota 1972, Kremer 1977, 1982), and for the salps Salpa fusiformis (Andersen \& Nival 1986). The constancy of the specific metabolic rate of gelatinous organisms could be related to their continuous growth, even during the reproduction period, and also to their low amount of living organic tissue (Kremer 1977, Larson 1985, Matsakis 1990). The linear dependence between excretion rate and organism size is not typical for most gelatinous zooplankton, especially in ctenophores, as reported previously (Ikeda 1970, Miller 1970, Baker 1973).

Specific excretion rates of gelatinous predators generally range between 0.01 and $1.50 \mu \mathrm{g}$-at. $\mathrm{N}-\mathrm{NH}_{4}$ $\mathrm{mg}^{-1} \mathrm{~d}^{-1}$ (Jawed 1973, Kremer 1975, 1977, 1982, Purcell \& Kremer 1983, Schneider \& Weisse 1985, Morand et al. 1987, Youngbluth et al. 1988). Results for Clytia are higher and ranged between 1.9 and $18.1 \mu \mathrm{g}$-at. $\mathrm{N}-\mathrm{NH}_{4}$ $\mathrm{mg}^{-1} \mathrm{~d}^{-1}$ (Table 6). Measurements of specific excretion rates were done on immature individuals. The dry weight of Clytia spp. seems to contain more organic matter than other medusae, and therefore that higher amount leads to higher weight-specific excretion rates. If $b=1$, differences in dry weight and carbon content may perhaps lead to increased excretion rates in mature medusae.

An exponential increase of specific excretion rate with temperature is generally observed, as is the case for copepods (Nival et al. 1974), Salpa fusiformis (Andersen \& Nival 1986) and Mnemiopsis leidyi (Kremer 1975). For the higher food concentrations, Clytia spp. specific excretion rate increased with temperature up to $21^{\circ} \mathrm{C}$. A temperature of $25^{\circ} \mathrm{C}$ inhibited Clytia spp. feeding (see Matsakis 1990) and thus metabolic rates, and represented a critical temperature.

The $Q_{10}$ values are on the order of those reported for other gelatinous zooplankton (Kremer 1977, Andersen \& Nival 1986, Morand et al. 1987), ranging from 1.32 to 2.04 and tending to increase with food availability (Table 3). This suggests a decrease of metabolism and a lower sensitivity to thermal variation at low food concentrations.

Table 6. Daily nitrogen turnover of some gelatinous predators

\begin{tabular}{|c|c|c|c|}
\hline Taxon & $\begin{array}{l}\text { Nitrogen turnover } \\
\left(\mathrm{NH}_{4}{ }^{1} \% \mathrm{Nd}^{-1}\right)\end{array}$ & $\begin{array}{l}\text { Temperature } \\
\left({ }^{\circ} \mathrm{C}\right)\end{array}$ & Source \\
\hline Gelatinous zooplankton & $7.5-23$ & $23-29$ & Biggs (1977) \\
\hline $\begin{array}{l}\text { Hydromedusae } \\
\text { Clytia }\end{array}$ & $6.14-33.60$ & $15-21$ & This study \\
\hline $\begin{array}{l}\text { Scyphomedusae } \\
\text { Pelagia noctiluca }\end{array}$ & 12.8 & 26 & Biggs (1977) \\
\hline $\begin{array}{l}\text { Pelagia nociluca } \\
\text { Ephyrae } \\
\text { Adults }\end{array}$ & $\begin{array}{r}12.9 \\
2.4 \\
3.3 \\
6.7\end{array}$ & $\begin{array}{l}22 \\
16.5 \\
21 \\
24\end{array}$ & $\begin{array}{l}\text { Morand et al. (1987) } \\
\text { Morand et al. (1987) } \\
\text { Morand et al. (1987) } \\
\text { Morand et al. (1987) }\end{array}$ \\
\hline $\begin{array}{l}\text { Ctenophores } \\
\text { Mnemiopsis leidyi }\end{array}$ & $\begin{array}{l}4-10 \\
8.4\end{array}$ & $\begin{array}{l}25 \\
21.8\end{array}$ & $\begin{array}{l}\text { Kremer et al. (1986) } \\
\text { Kremer (1977) }\end{array}$ \\
\hline $\begin{array}{l}\text { Siphonophores } \\
\text { Agalma okeni } \\
\text { Sphaeronectes gracilis }\end{array}$ & $\begin{array}{l}8.4 \\
3.5\end{array}$ & $\begin{array}{l}26 \\
13\end{array}$ & $\begin{array}{l}\text { Biggs (1976) } \\
\text { Purcell \& Kremer (1983) }\end{array}$ \\
\hline
\end{tabular}


One of the few studies considering the effect of controlled food level on the metabolic rate of carnivores (Reeve et al. 1978) showed higher respiration and excretion rates in Pleurobrachia bachei reared with concentrations of 10 vs 100 prey $\mathrm{I}^{-1}$. Kremer (1982) reported for Mnemiopsis mccradyi an increase by a factor of 1.4 in respiration rate and 1.7 in excretion rate when food concentration increased from 5 to 50 prey ${ }^{-1}$. A similar increased was observed by Purcell \& Kremer (1983) for the siphonophore Sphaeronectes gracilis when food concentration increased from 5 to 20 prey $\mathrm{l}^{-1}$. The excretion rate of Clytia spp. increased by factors of 6.60 , 2.62 , and 8.27 when food availability increased from 7 to 25 copepods $\mathrm{I}^{-1}$ at 15,18 and $21^{\circ} \mathrm{C}$ respectively.

Because of its watery composition, Clytia spp. is deceptively large for its organic content. Thus the excretion rate, which does not seem important when described as a function of size, represents in reality a very rapid turnover of nitrogen. According to Kremer (1977), ctenophores of Narragansett Bay (Rhode Island, USA) 'pump' nitrogen very rapidly through food consumption without binding these elements in their structure. We can suppose that the same phenomenon occurs in Clytia spp. which has a daily nitrogen turnover of $>10 \%$ (Table 6 ). This high metabolic rate is confirmed by the rapid shrinkage of unfed medusae (Laval 1971, Matsakis 1990). Apparently, as food becomes scarce and medusae are unable to grow, a substantial part of their body tissue is involved in maintenance. The daily nitrogen turnover of hydromedusae is generally higher than that for other gelatinous zooplankton (Table 6).

Using the present data on ammonia excretion of Clytia spp., I attempted to estimate the potential daily growth budget for Clytia spp. in the Bay of Villefranche-sur-Mer. The Clytia spp. abundance at Point B of the Bay was determined from March 1987 to February 1988 from zooplankton samples. The Clytia spp. were present in the Bay throughout the year with highest densities from March to June (ca 25 ind. $100 \mathrm{~m}^{-3}$ ); they became relatively scarce from July to the end of August $\left(<5\right.$ ind $100 \mathrm{~m}^{-3}$ ) and after this time their population increased again (Fig. 3A). During autumn and winter, the population consisted only of small size individuals ( $\leq 5 \mathrm{~mm}$ diameter). To calculate the mean individual growth budget we assumed that the average medusan diameter was about $5 \mathrm{~mm}$ during winter, and $7 \mathrm{~mm}$ during the rest of the year.

During the same sampling period (March 1987 to February 1988), zooplankton gathered at Point B in the Bay (using a $200 \mu \mathrm{m}$ mesh net daily towed vertically from $-75 \mathrm{~m}$ to the surface) documented a concentration of potential prey for Clytia spp. of more than $15.63 \times$ $10^{3} \mathrm{~m}^{-3}$ during the spring bloom to $0.01 \times 10^{3} \mathrm{~m}^{-3}$ during winter months (Fig. 3B) (Matsakis 1990).
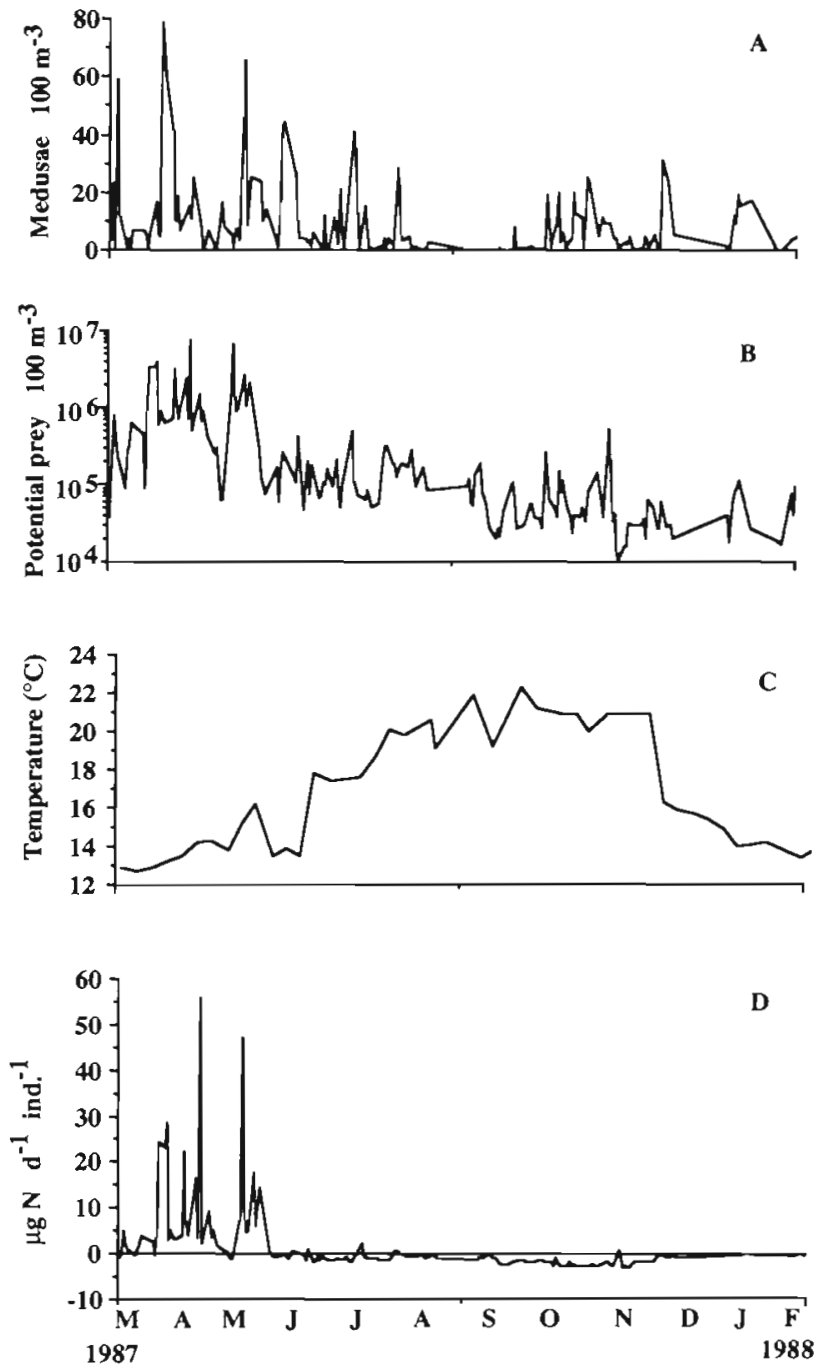

Fig. 3. Clytia spp. Growth budgets of hydromedusae from March 1987 to February 1988. (A.) Seasonal variations of Clytia abundance at the reference station (Point B) in the Bay of Villefranche-sur-Mer (30 m depth); (B) seasonal abundance of potential prey $(250$ to $550 \mu \mathrm{m})$ for medusae; (C) temperature at $30 \mathrm{~m}$ depth in the Bay; (D) growth budget $\left\{G, \mu \mathrm{g} \mathrm{N} \mathrm{d^{-1 }}\right.$ ind.-1) of Clytia spp.

The growth budget $G$ ( $\mu \mathrm{g} \mathrm{N} \mathrm{d} \mathrm{d}^{-1}$ ind. ${ }^{-1}$ ) is the difference between the quantity of assimilated materials and the material lost by ammonia excretion. It can be expressed by:

$$
G=A-E,
$$

where $E=$ the daily ammonia excretion rate $(\mu \mathrm{g}$-at. $\mathrm{N}-\mathrm{NH}_{4} \mathrm{~d}^{-1}$ ind ${ }^{-1}$ ) from Eq. 5; and $\mathrm{A}=$ the quantity of materials assimilated daily and thus available for the organism maintenance. A corresponds to the product of the predation rate by assimilation coefficient. The assimilation coefficient is assumed to be 0.8 for gelatinous predators (see review in Larson 1985). 
Predation rate $I$ (prey ind.$^{-1} \mathrm{~h}^{-1}$ ) of Clytia spp. increases linearly (slope $=0.065$ ) with prey concentration up to a concentration of about 140 prey ${ }^{-1}$ (Matsakis \& Nival 1989). We can assume that the mean nitrogen content of a prey is $0.6 \mu \mathrm{g}$ (Matsakis \& Nival 1989).

Temperature and prey concentration in the Bay of Villefranche-sur-Mer vary throughout the year (Fig. 3B, C). Assuming that one can extrapolate the equation determined from experimental results to the natural environment, it is possible to estimate the in situ growth budget of medusae, and to find out whether it is in agreement with the abundance periods of Clytia spp. in the Bay. Fig. 3 shows that when prey are abundant, $G$ is positive; at this time, the temperature at $30 \mathrm{~m}$ depth increases from 12.8 to $15^{\circ} \mathrm{C}$. As temperature increases, the potential prey concentration decreases and daily rations become lower. At this time, prey concentration is very low and does not allow hydromedusa growth (Matsakis 1990), and $G$ becomes slightly negative. This period coincides with the low abundance of Clytia spp. in early summer. We suggest here that, in order to survive from June to July, the medusae must shift their predation to other prey types. The disappearance of Clytia spp. in August and early September may be related to a reduction in medusae production by benthic hydrozoans of Clytia spp., or it could be related to the appearance of predators, perhaps the Trachymedusae Liriope tetraphylla, which became very abundant at that time (Matsakis 1990).

Acknowledgements. This work was supported by Centre National de la Recherche Scientifique (CNRS), research group UA 716. I thank Marie-Dominique Pizay for her assistance in ammonia measurements. Drs Paul Nival and Robert J. Conover kindly reviewed the manuscript during its preparation

\section{LITERATURE CITED}

Alldredge, A. L., Robinson, B. M., Fleminger, A., Torres, I., King, H. Hamner, W. M. (1984). Direct sampling and in situ observations of a persistent copepod aggregation in the mesopelagic zone of the Santa Barbara Basin. Mar. Biol. 80: 75-82

Andersen, V., Nival, P. (1986). Ammonia excretion rate of Salpa fusiformis (Cuvier) (Tunicata: Thaliacea): effects of individual weight and temperature. J. exp. mar. Biol. Ecol. 99: $121-132$

Baker, L. D. (1973). Ecology of the ctenophore Mnemiopsis leidyi Mayer, in the Biscane Bay, Florida. Tech. Rep. UMRSMAS-73016, Rossentiel School of Marine Atmospheric Science, Univ. of Miami

Bảmstedt, U. (1985). Seasonal excretion rates of macrozooplankton from the Swedish west coast. Limnol. Oceanogr. 11: $520-528$

Bıggs, D C. (1977). Respiration and ammonia excretion by open ocean gelatinous zooplankton. Limnol. Oceanogr. 22: $108-118$
Corner, E. D. S., Conwey, C. B., Marshall S. M. (1965). On the nutrition and metabolism of zooplankton. III. Nitrogen excretion by Calanus. J. mar. biol. Ass. U.K. 45: 429-442

Corner, E. D. S., Davies, A. G. (1971). Plankton as a factor in the nitrogen and phosphorus cycles in the sea. Adv. mar. Biol. 9: 102-204

Cornelius, P. F. S. (1982). Hydroids and medusae of the family Campanulariide recorded from the eastern North Atlantic, with a world synopsis of genera. Bull. Br. Mus. nat. Hist (D: Zool.) 42: 37-148

Dagg, M. J., Cowels, T., Withledges, T., Smiths, S., Howe, S., Judkingsi, D. (1980). Grazing and excretion by zooplankton in the Peru upwelling system during April 1977. Deep Sea Res. 27A: 43-59

Eppley, R. W., Rengere, H., Venrick, E. L., Mullin, M. M. (1973). A study of planktonic dynamics and nutritent cycling in the central gyre of the North Pacific Ocean. Limnol. Oceanogr. 18: 534-551

Goy, J. (1968). Les hydroméduses de la rade de Villefranchesur-Mer et de la mer de Ligurie. Thése de $3^{\text {mane }}$ cycle, Fac. Sci. Paris

Hamner, W. M, Madin, L. P., Alldredge, A. L., Gilmer, R. W., Hamner, P. P. (1975). Underwater observations of gelatinous zooplankton: sampling problems, feeding biology and behavior. Limnol. Oceanogr. 20: 907-917

Harbison, G. R., Madin, L. P., Swanberg, N. R. (1978). On the natural history and distribution of oceanic ctenophores. Deep Sea Res. 25: 233-256

Harris, E. (1959). The nitrogen cycle in Long Island Sound. Bull. Bingham oceanogr. Coll. 17: 31-65

Hirota, J. (1972). Laboratory culture and metabolism of the planktonic ctenophore, Pleurobrachia bachei, A. Agassiz. In: Takenouti, A. Y. (ed.) Biochemical oceanography of the Northern Pacific Ocean. Indemitsu Shoten, Tokyo, p. $465-484$

Ikeda, T. (1970). Relationships between respiration rate and body size in marine plankton animal as a function of the temperature habitat. Bull. Fac. Fish. Hokkaido Univ. 21: $91-112$

Ikeda, T. (1974). Nutritional ecology of marine zooplankton as a function of body mass and temperature. Mem. Fac. Fish. Hokkaido Univ. 22: 1-97

Ikeda, T., (1985). Metabolic rates of epipelagic marine zooplankton as a function of body mass and temperature. Mar. Biol. 85: 1-11

Jawed, M. (1973). Ammonia excretion by zooplankton and its significance to primary productivity during summer. Mar. Biol. 23: 115-120

Koroleff, F. (1969). Direct determination of ammonia in sea water as indophenol blue. Int. Counc. Explor. Sea. Comm. Meet. 12: 11-19

Kramp, P. L. (1961). Synopsis of medusae of the world. J. mar. biol. Ass. U.K. 40: 1-496

Kremer, P. (1975). Nitrogen regeneration by the ctenophore Mnemiopsis Jeidyi. In: Howell, F. G., Gentry, G. R., Smith, M. H. (eds.) Mineral cycling in southeastern ecosystrm. ERDA (Environ. Res. Dev. Adm.) symp. ser. 1975: $279-290$

Kremer, P. (1977) Respiration and excretion by the ctenophore Mnemiopsis leidyi. Mar. Biol. 44. 43-55

Kremer, P. (1982). Effect of food availability on the metabolism of the ctenophore Mnemropsis leidyi. Mar. Biol. 71. $149-156$

Kremer, P., Reeve, M. R., Syms, M. A. (1986). The nutritional ecology of the ctenophore Bolinopsis vitrea: comparison with Mnemiopsis mccradyl from the same region. J. Plankton Res. 8: 1197-1208 
Kremer P., Kremer, J. N. (1988), Energetic and behavioral implications of pulsed food availability for zooplankton. Bull. mar. Sci. 43: $797-809$

Larson, R. J. (1985). Trophic ecology of gelatinous predators (Cnidaria and Ctenophora) in Saanich Inlet, Vancouver P.S., B.C., Canada. Ph.D. thesis, Univ. of Victoria, Canada

Laval, P. (1971). Comportement, parasitisme et écologie d'Hyperia schizogeneios Stebb (Amphipode, Hypéride) dans le plancton de Villefranche-sur-Mer. Annls Inst océanogr. Paris 48(1): 49-79

Maclsaac, J. J., Dugdale, R. G. (1972). Interactions of light in inorganic nitrogen in controlling nitrogen uptake in the sea. Deep Sea Res. 19: 209-232

Martin, J. H. (1968). Phytoplankton relationships in Narra gansett Bay. III. Seasonal changes in zooplankton excretion rates in relation to phytoplankton abundance. Limnol. Oceanogr 13:63-71

Matsakis, S., Nival, P. (1989). Elemental composition and food intake of Phialidium hydromedusae in the laboratory J. exp. mar. Biol. Ecol. 130: 217-290

Matsakis, S. (1990). Comportement et métabolisme de quelques méduses en Mer Ligure et dans le Bassin de Bedford. Doctorate thesis, Univ. of Paris VI

Mayzaud, P., Dallot, S. (1973). Respiration et excrétion azotée du zooplancton. I. Evaluation des niveaux métaboliques de quelques espèces de Méditerranée occidentale. Mar. Biol. 19: 307-314

Miller, R. J. (1970). Distribution and energetics of estuarine population of the ctenophore Mnemiopsis leidyi. Ph.D. dissertation, North Carolina State Univ., Raleigh

Morand, P., Carré, C., Biggs, D. C. (1987). Feeding and metabolism of the jellyfish Pelagia noctiluca. J. Plankton Res, 9:651-665

Nival, P., Malara, G., Charra, R., Palazzoli, I., Nival, S. (1974). Etude de la respiration et de l'excrétion de quelques copépodes planctoniques (Crustacea) dans la zone de

This article was submitted to the editor remontée d'eau profonde des côtes marocaines. J exp. mar. Biol. Ecol. 15: 231-261

Purcell, J. E., Kremer, P. (1983). Feeding and growth of the siphonophore Sphaeronectes gracilis. J. Plankton Res. 5: 95-106

Reeve, C. R. (1940). Relative growth in the snout of anteaters. A study in the application of quantitative methods of systematics. Proc. zool. Soc. Lond. 110:47-80

Recve, M. R., Walter, M. A., Ikeda, T. (1978). Laboratory studies of ingestion and food utilization in lobate and tentaculate ctenophores. Limnol. Oceanogr 23: 740-751

Schneider, G., Weisse, T. (1985). Metabolism measurements of Aurelia aurita planulae larvae, and calculation of maximal survival period of the free swimming stage. Helgoländer Meeresunters, 39:43-47

Schneider, G. (1989). The common jellyfish Aurelia aurita: standing stocks, excretion and nutrient regeneration in the Kiel Bight, Western Baltic. Mar. Biol. 100: 507-514

Sokal, R. R., Rohlf, F. J (1981). Biometry, 2nd edn. W. H. Freeman, San Francisco

Strickland, J. D. H., Holm-Hansen, O., Eppley, R. W., Linn, R. J. (1969). The use of a deep tank in plankton ecology. I. Study of the growth and composition of phytopankton crops at low nutrient levels. Limnol. Oceanogr. 14: 23-24

Tréguer, P., Le Corre, P. (1975). Manuel d'analyse des sels nutritifs dans l'eau de mer, $2^{\text {enn }}$ édition. Université de Bretagne Occidentale, Brest

Williams, R., Conway, D. V. P. (1981). Vertical distribution and seasonnal abundance of Agantha digitale (Muller) (ccelenterate: Trachymedusae) and other planktonic invertebrates in Northeast Atlantic Ocean. J. Plankton Res. 3: $634-643$

Youngbluth, M. J., Kremer, P., Bailey, T. G., Jacoby, C. A. (1988). Chemical composition, metabolic rates and feeding behavior of the midwater ctenophore Bathocyroe fosteri. Mar. Biol. 98: 87-94

Manuscript first received: January 29, 1992

Revised version accepted: August 18, 1992 